Limnol. Rev. (2016) 16, 3: 155- 164

\title{
Using GIS to discover changes in the local water cycle of wetlands - case study Poblockie Peatbog
}

\author{
Magda Sikora, Roman Cieśliński \\ Departament of Hydrology, University of Gdańsk, Bażyńskiego 4, 80-309 Gdansk, Poland, \\ e-mail: magda_sikora3@wp.pl; georc@univ.gda.pl (corresponding author)
}

\begin{abstract}
The aim of this study is to reconstitute the changes in the local water cycle and plant habitats occurring in wetlands under anthropic influence. The selected area for the study in this paper is the swamp of Pobłockie Peatbog, located in the catchment area of the river Łeba in northern Poland. The fieldwork was performed in October of 2013. Using ArcMap the hydrographic network of the study area in the years 1837, 1918, 1936, 1976 and 2000 were digitized and represented. Using a LIDAR image, the terrain model for the swamp of Pobłockie Peatbog was generated in ArcMap. This was then used to create a map showing the location of runoff pathways from the waterlogged areas. Long-term drainage and the construction of new drainage ditches have led to the encroachment of bog woodland on the originally treeless swamp of Pobłockie Peatbog.
\end{abstract}

Keywords: GIS tools, habitat, peat bog, water cycle, wetlands

\section{Introduction}

Wetlands are extremely important elements in geographical space due to their retention potential, numerous hydrological functions and - primarily - biological values (a large variety of species) (Oertli et al. 2005). Together with their catchments, wetlands often form isolated areas (Brooks and Hayashi 2002; Brooks $2004,2005)$. At the same time, due to natural or anthropogenic changes they may, alongwith other hydrographic components situated in the area, create entire hydrographic systems linked via hydraulic bonds (Tiner 2003). Their existence, as well as the composition of species occurring in wetland habitats, has always been associated with water resources and water circulation, so it is important to know and reconstitute the water budgets in their area. This gives the opportunity to explore changes in the environment that have occurred in wetlands (Leider et al. 2013). Unfortunately, due to irresponsible human activity the surface area of world wetlands has drastically decreased, thereby causing a distortion of the existing water circulation, not only on a local or regional scale, but also on a global scale. This is another contributing factor to the decline of water resources in the world (Rijsberman 2006), largely re- sulting from attempts to use the land for agricultural purposes (Muller et al. 2013).

In many cases, the processes and phenomena occurring in wetlands, as well as natural and anthropogenic changes in such areas are subjected to mathematical modelling (Krysanova et al. 2005; Davis et al. 2005) or are studied with the use of remote sensing and GIS tools (Papastergiadou et al. 2008). Numerous papers describe cause and effect relationships between groundwater and surface water in wetlands and groundwater impact on the existence of these areas (Antonellini and Mollema 2010; Miguez-Macho and Fan 2012), while Nuttle and Hemand (1988) and Wilcox et al. (2002) describe the connections between biota and hydrological conditions occurring in wetlands. The most important would appear to be water level changes and the time periods of hydration and reduction of water resources (Stefanidis and Papastergiadou 2013).

The selected study area for this paper is the swamp of Pobłockie Peatbog, located in the catchment of the River Łeba in northern Poland, in the Pomorskie Voivodeship. This is situated within the range of the Scandinavian ice sheet, in the ice marginal stream valley of the watercourse of the Główczycka Struga, south of Lake Łebsko and west of the Łeba-Reda post-glacier 


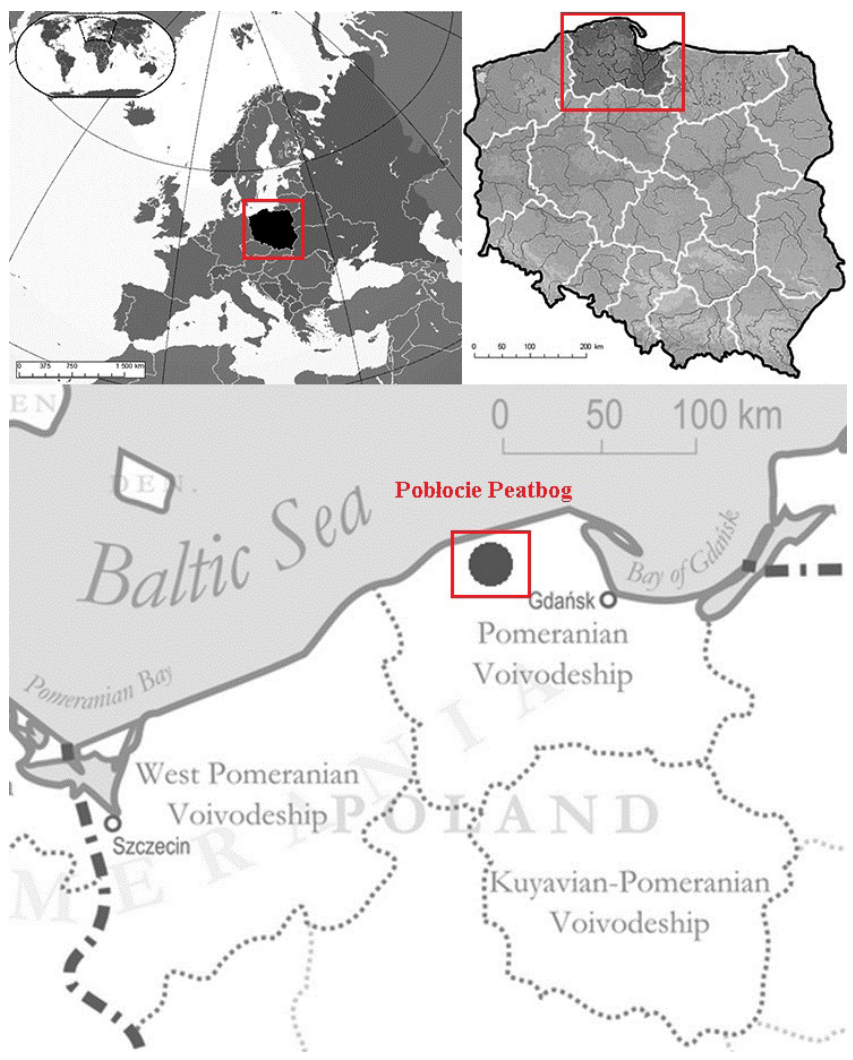

Fig. 1. Location of the study area valley (Fig. 1). Geographically, the swamp of Pobłockie Peatbog lies in the South Baltic Coastland, and hydrologically it belongs to wetlands. On the other hand, from a biological point of view the study area is considered to be a Baltic-type raised bog which creates a unique plant habitat occurring only in a narrow strip of coastland. The topography of the analysed area is not very diverse. Based on the terrain model obtained from the images of the LIDAR (Fig. 2) it is clear that the highest part of the wetland is the dome of a raised bog developed here while the lowest is the north-eastern part, the former site of Lake Czarne.

The aim of this study is to reconstitute changes in the local water cycle and plant habitats occurring in wetlands under the influence of anthropopressure. These studies are important because they can provide valuable information with respect to the reforestation of wetlands or periods and causes of water scarcity.

\section{Methods}

The research procedure involved a search for source materials, during which cartographic material used in this study was collected. To identify changes in the hydrographic network of the swamp of Pobłockie Peatbog, the following maps were selected:

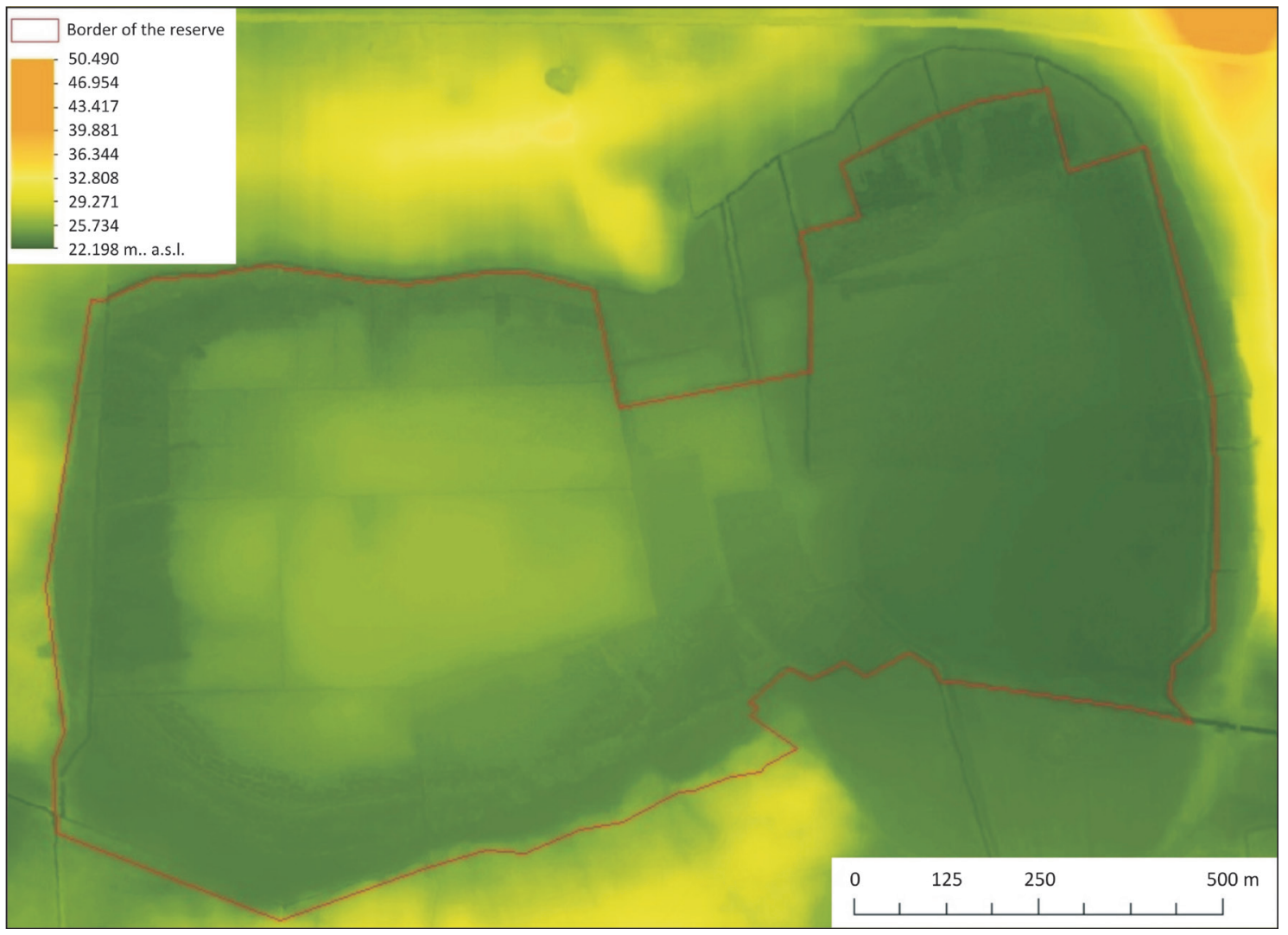

Fig. 2. Terrain model based on the LIDAR image 
- Topographic map of Poland on the scale 1:10 000 , sheets N-33-59-B-b-2 and N-33-59-B-b-4 (as of 2000),

- Topographic map of Poland on the scale 1:25 000, sheet N-33-59-Bb Rzuszcze (as of 1976),

- Topograpfische Karte on the scale 1:25 000, sheet 1370 Glowitz sheet (as of 1936 ),

- Topographic map of Poland on the scale 1:25 000, sheet 1370 Główczyce (based on the German map of 1918),

- German military map, sheet 217 Glowitz of 1837 made by von Clausewitz Lt. of the 11th Regiment To identify changes in plant habitats in the study area the phytosociological study taken in 2011 was used.

Using ArcMap the hydrographic network of the study area in the years 1837, 1918, 1936, 1976 and 2000 was vectorised and represented. Using the LIDAR image received from the Centre for Geodesy and Cartography Documentation in Warsaw, a terrain model for the swamp of Pobłockie Peatbog was built in ArcMap. This was then used in SagaGis to generate a map showing the location of runoff pathways from the waterlogged areas, using the D8 (deterministic eight-node) single-flow-direction (SFD) algorithm (Gallant and Wilson 2000).

The above procedure was complemented by fieldwork whose task was to verify the existing hydrographic network and hydraulic engineering structures in the study area, which was undertaken in October 2013. The result of this work led to the preparation of a hydrographic image of the study area.

\section{Results}

There are three key issues relating to the hydrology of wetlands. These include excessive drainage, loss of a natural draining system on the edges of the waterlogged area and the protection of bogs. In many cases conservation relies on the prevention of any conservation measures, which in the case of peatlands leads to the spread of forest in the wetland and ultimately to increased interception and transpiration (Whitefield et al. 2006). Many waterlogged areas with peat deposits struggle with these problems, which first lead to the drying of the peatbog surface, peat decay and, consequently, to the disappearance of the peatbog. Reference to historical maps that contain a record of changes in the hydrographic network can, in many cases, show how the hydrographical network has changed, when the drainage ditches were built and how land use was transformed. These types of observations were conducted with regard to the swamp of Pobłockie Peatbog.

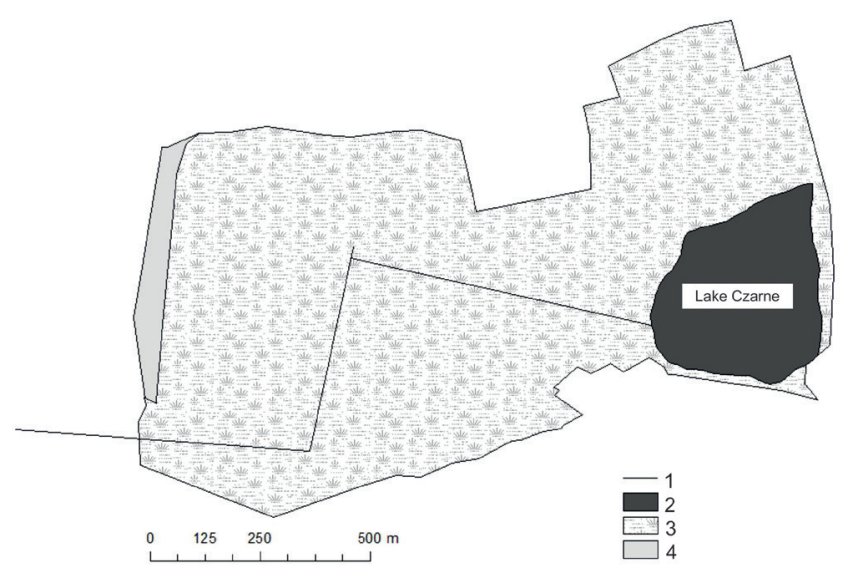

Fig. 3. Hydrographic network of the swamp of Pobłockie Peatbog in 1837

Explanation: 1 - streams, 2 - reservoir, 3 - swamps, 4 - border of the reserve.

As the oldest map of 1837 shows (Fig. 3) the area of the swamp of Pobłockie Peatbog was generally not drained but had one canal (1556 m), which connected Lake Czarne with the watercourse of the Struga Główczycka. Lake Czarne existed and is clearly visible on this map (12.7 ha). The area was deforested and waterlogged.

The map which shows the state of the research area in 1918 (Fig. 4) indicates that in the waterlogged area there were only a few ditches, including some surrounding collector ditches. The length of the ditches in the waterlogged area was $3.81 \mathrm{~km}$, and the hydrographic network density was $3.40 \mathrm{~km} \mathrm{~km}^{-2}$. At that time intensive peat extraction was conducted in Pomerania.

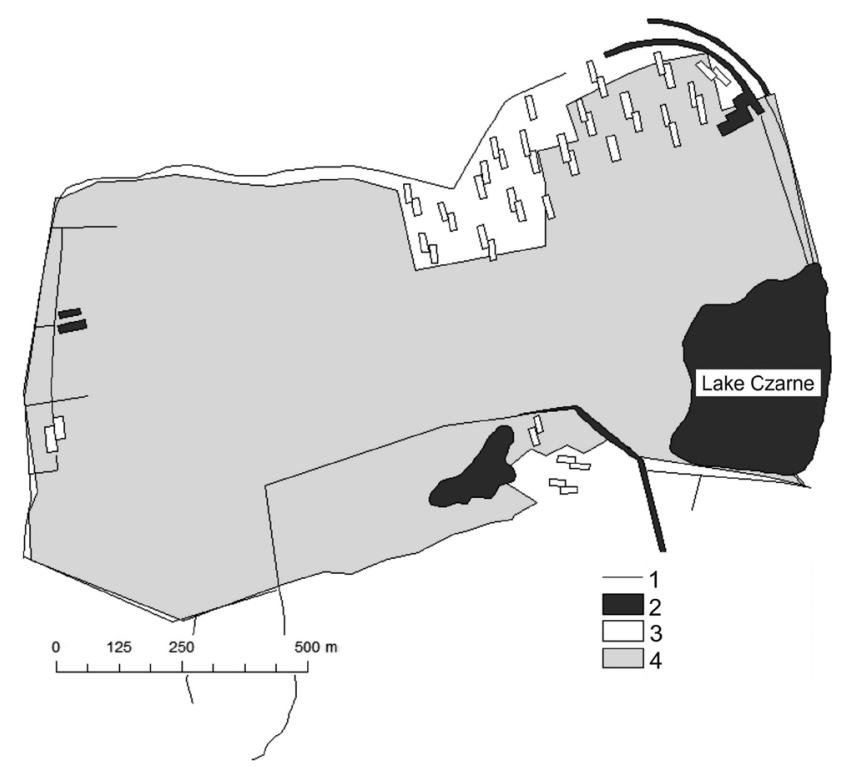

Fig. 4. Hydrographic network of the Pobłockie Peatbog swamp in 1918

Explanation: 1 - stream, 2 - reservoir, 3 - peat extraction site, 4 - border of the reserve. 


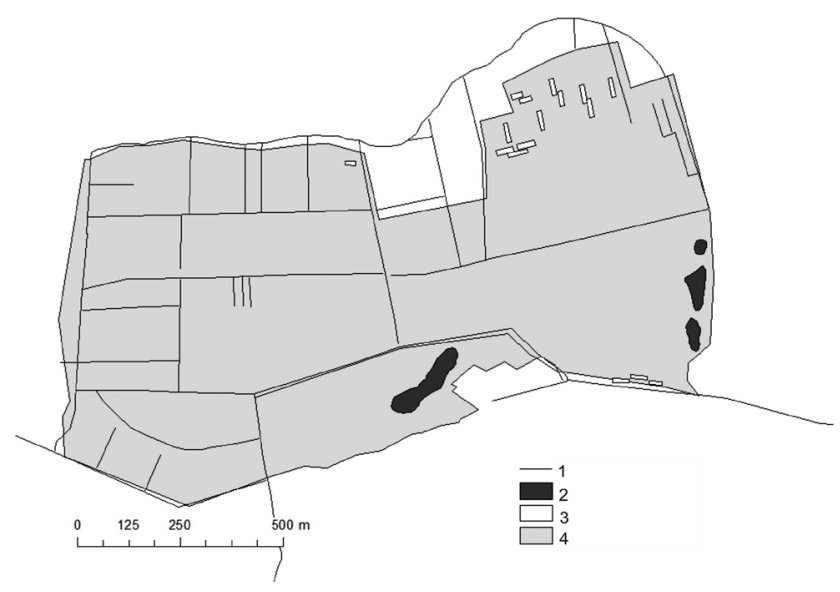

Fig. 5. Hydrographic network of the Pobłockie Peatbog swamp in 1936

Explanation: 1 - stream, 2 - reservoir, 3 - peat extraction site, 4 - border reserve.

This was also the case of the swamp of Pobłockie Peatbog. Peat extraction was most intense in its north-eastern part, probably as a result of good communication (short distance from the road). The map also shows traces of peat extraction in the south-eastern part of the waterlogged area, as well as in two places on its western side. The surface area of the disused peat pits marked on the map was 2.56 ha. At the beginning of the twentieth century the natural reservoir of Lake Czarne, of an area of 9.89 ha. could be seen in the south-eastern part of the area. To the west of Lake Czarne there was one small reservoir of 1.28 ha while in the northern part of the waterlogged area there was another small reservoir which - judging by its shape - was of anthropogenic origin. The canal that connected Lake Czarne with the Struga Główczycka on the map of 1837 can no longer be seen.

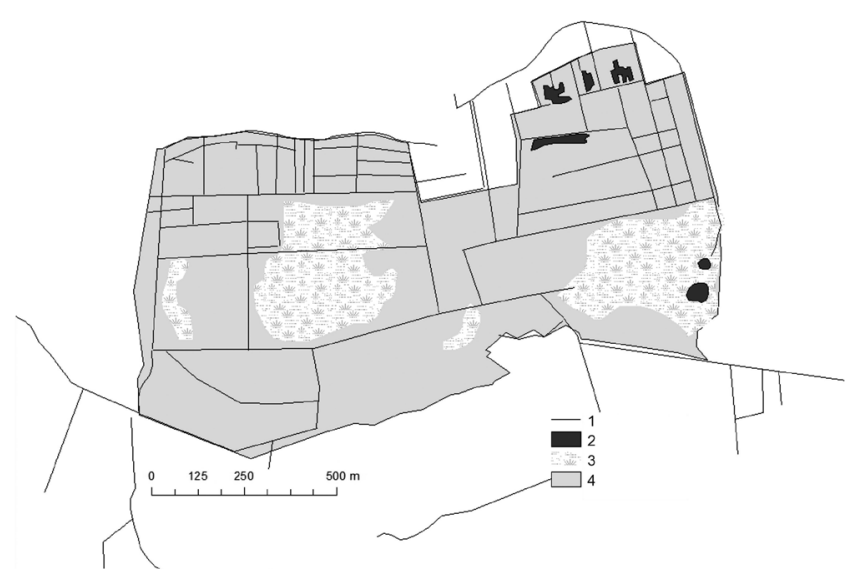

Fig. 6. Hydrographic network of the Pobłockie Peatbog swamp in 1976

Explanation: 1 - stream, 2 - reservoir, 3 - swamps, 4 - border of the reserve.
Decreasing peat extraction in subsequent years resulted in a lower number of pits visible on the map of 1936 (Fig. 5). Their area was reduced from 2.56 ha in 1918 to 0.68 ha. Lake Czarne no longer existed, and in its place there were three small water bodies constituting its remains. In turn, the second largest reservoir decreased in size from 1.26 ha (1918) to 0.83 ha. This shows that in the area of the Pobłockie Peatbog swamp water conditions had changed, i.e. there had been a decrease in its water supply and its drainage. Confirmation of this statement is provided by the system of drainage ditches seen in the central part of the waterlogged area. Their length was $9814 \mathrm{~m}$, and the hydrographic network density was $8.76 \mathrm{~km} \mathrm{~km}^{-2}$.

From the map showing the state of the hydrographic network in 1976 (Fig. 6) some newly dug ditches can be seen, which caused further drainage of the area. In the place of Lake Czarne only two small reservoirs have survived, while in the north-eastern part four additional reservoirs can be seen, probably developed from post-extraction peat pits. What can also be seen are two waterlogged areas, one in the place of the former location of Lake Czarne and the other in the western part of the waterlogged area. Waterlogged areas occupy only 22.26 ha, while in 1837 almost the entire study area had been waterlogged (108.94 ha).

The topographic map on the scale 1:10 000 printed in 2000 (Fig. 7) shows that the number of ditches had decreased by $1.16 \mathrm{~km}$ compared to the 1976 map, and thus they had a total length of $13.30 \mathrm{~km}$. This change is most noticeable in the north-western part of the waterlogged area. On the other hand, in the northeastern part of the waterlogged area, only one water body remained out of four visible on the map of 1976 . Simultaneously, the surface area of the constantly wa-

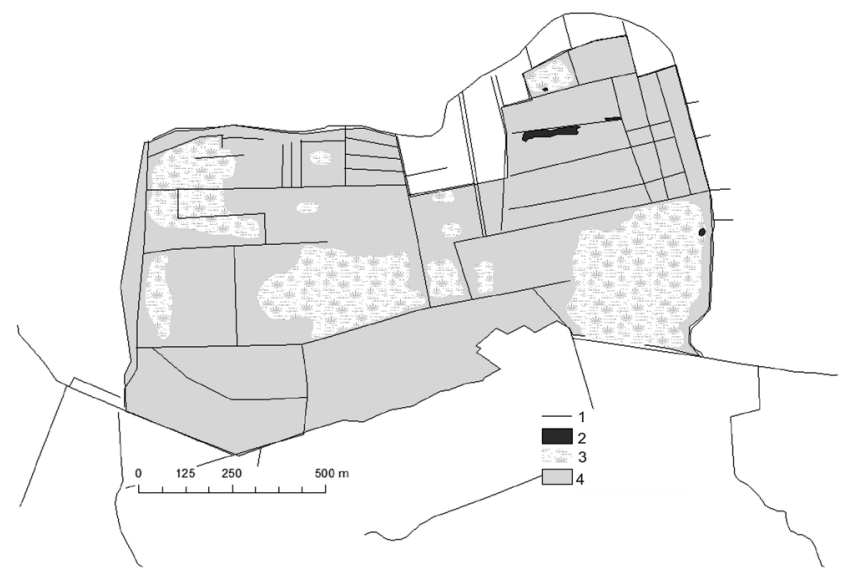

Fig. 7. Hydrographic network of the Pobłockie Peatbog swamp based on the topographic map of Poland at 1:10 000, sheets N-3359-Bb-2, N-33-59-Bb-4

Explanation: 1 - stream, 2 - reservoir, 3 - swamp, 4 - border of the reserve. 


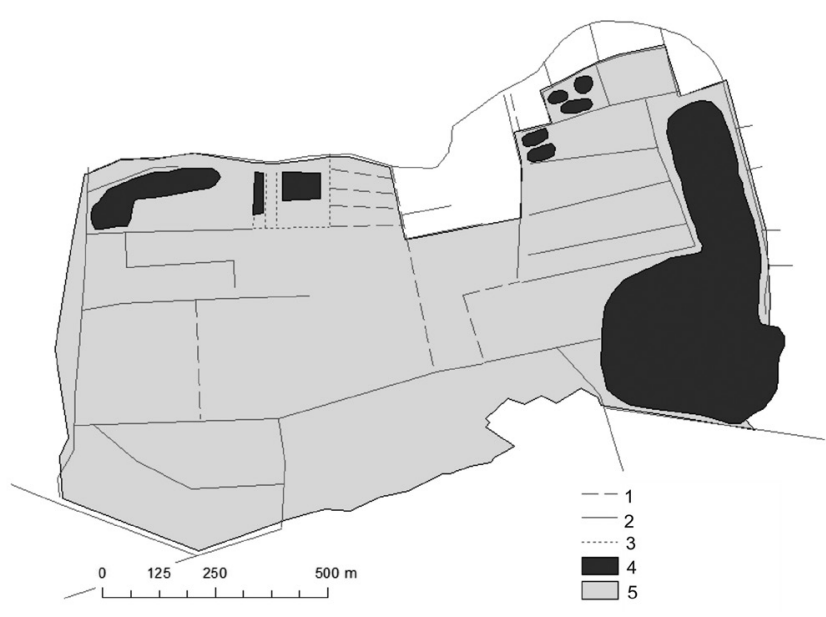

Fig. 8. Hydrographic network as recognised during the mapping on 24 Nov. 2013

1 - dry ditch, 2 - ditch with water, 3 - overgrown ditch, 4 - reservoir, 5 border of the reserve.

terlogged area shows an increase. Its area was 26.72 ha. This demonstrates the improved water conditions in the study area.

During mapping in November 2013 (Fig. 8), a decrease of $1.48 \mathrm{~km}$ in the number of drainage ditches was observed in the reserve compared to the topographic map of 2000. The hydrographic network density was $10.55 \mathrm{~km} \mathrm{~km}^{-2}$. Despite such a large density of existing drainage ditches, many of them were dry or overgrown. There were also water bodies visible, which had most likely developed when the protective measures were applied to the area of the swamp of Pobłockie Peatbog. As part of the protection of this area, ditche clearance was halted and the drainage from the waterlogged areas was blocked which resulted in a rise of the groundwater volume in the swamp. A major role in restoring appropriate dampness to the swamp of Pobłockie Peatbog was also played by beavers, whose

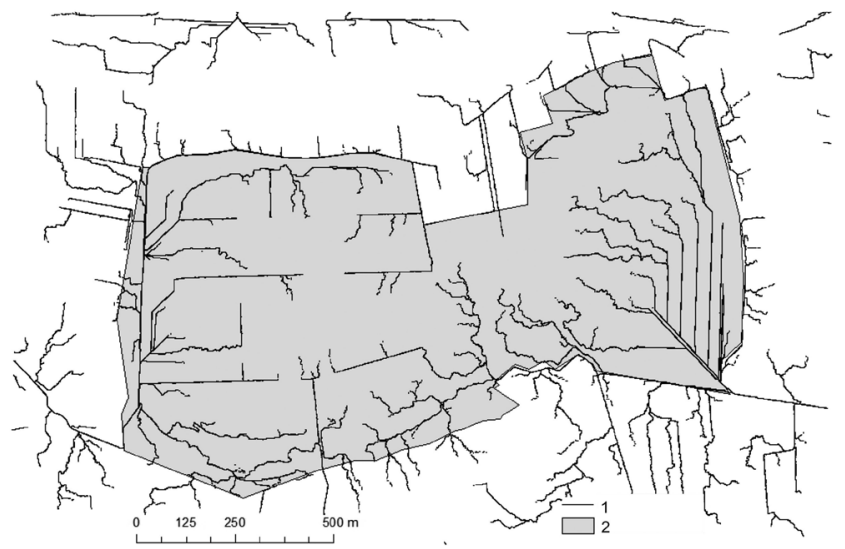

Fig. 9. Pathways of water outflow from the Pobłockie Peatbog swamp generated with the use of SagaGis model of the Catchment Area Explanation: 1 - main paths of outflow, 2 - border of the reserve. dams and lodges have also contributed to raising the water level in the research area. During the mapping an extensive backwater area was recorded in the eastern part of the waterlogged area; a result of beaver activity. In the southern part of the swamp other water bodies were found, one of which was a disused pit.

Within the study area the depth of the groundwater varies from 0.1 to $1.0 \mathrm{~m}$. In the peat bog dome the water level is about $30 \mathrm{~cm}$ below the surface, while in the western and north-western parts the water depth is below $40 \mathrm{~cm}$. In the south-eastern part the groundwater level is the highest and reaches from 10 to $20 \mathrm{~cm}$.

The model of runoff accumulation helped in determining the outflow pathways from the swamp of Pobłockie Peatbog (Fig. 9). The straight sections presented in the model confirm the anthropogenic origin of the hydrographic system in the area. Most of the ditches and canals, even though they are overgrown, still play their drainage role, as evidenced by the drying of the swamp.

Vegetation changes in the swamp are autogenic or allogenic. Autogenic succession occurs in relatively stable external conditions and is caused by vegetation, which may significantly change the characteristics of habitats. Allogenic succession, on the other hand, is caused by external factors which affect the waterlogged area. These may be both natural and anthropogenic factors. The main factor causing changes in plant habitats is always water. Therefore, any change in the manner and intensity of the swamp water supply affects the vegetation. Drainage of peat deposits is considered to be the main reason for changes in swamp habitats. The consequence is a change in vegetation (Ilnicki 2002). Moreover, the supply of significant quantities of biogenic compounds and their transformation significantly affect plant habitat change (Jahangir et al 2013; McPhillips et al. 2015).

In the research area, a component of Natura 2000, PLH220042 Pobłockie Peatbog, there are seven of the natural habitat types described in Annex I of the Habitats Directive. They are as follows: 3160 - Natural dystrophic lakes and ponds; 4010 - Damp heaths with the crossedleaved heath (Erica tetralix); 7110 - Raised bogs of peatforming vegetation (live); 7120 - Degraded raised bogs, capable of natural and/or stimulated regeneration; 7140 - Transition mires and quaking bogs (mostly with vegetation of the class Scheuchzerio-Caricetea nigrae); 91D0 - Bog woodland; 91E0 - Riparian willow, poplar, alder and ash forest (Salicetum albae, Populetum albae, Alnenion glutinoso-incanae, riparian alder forest).

While conducting fieldwork in biology in 2011 (phytosociological research) (Fig. 10) most of the habitats listed in the Habitats Directive were recorded. However, there was no occurrence of natural, dystrophic 


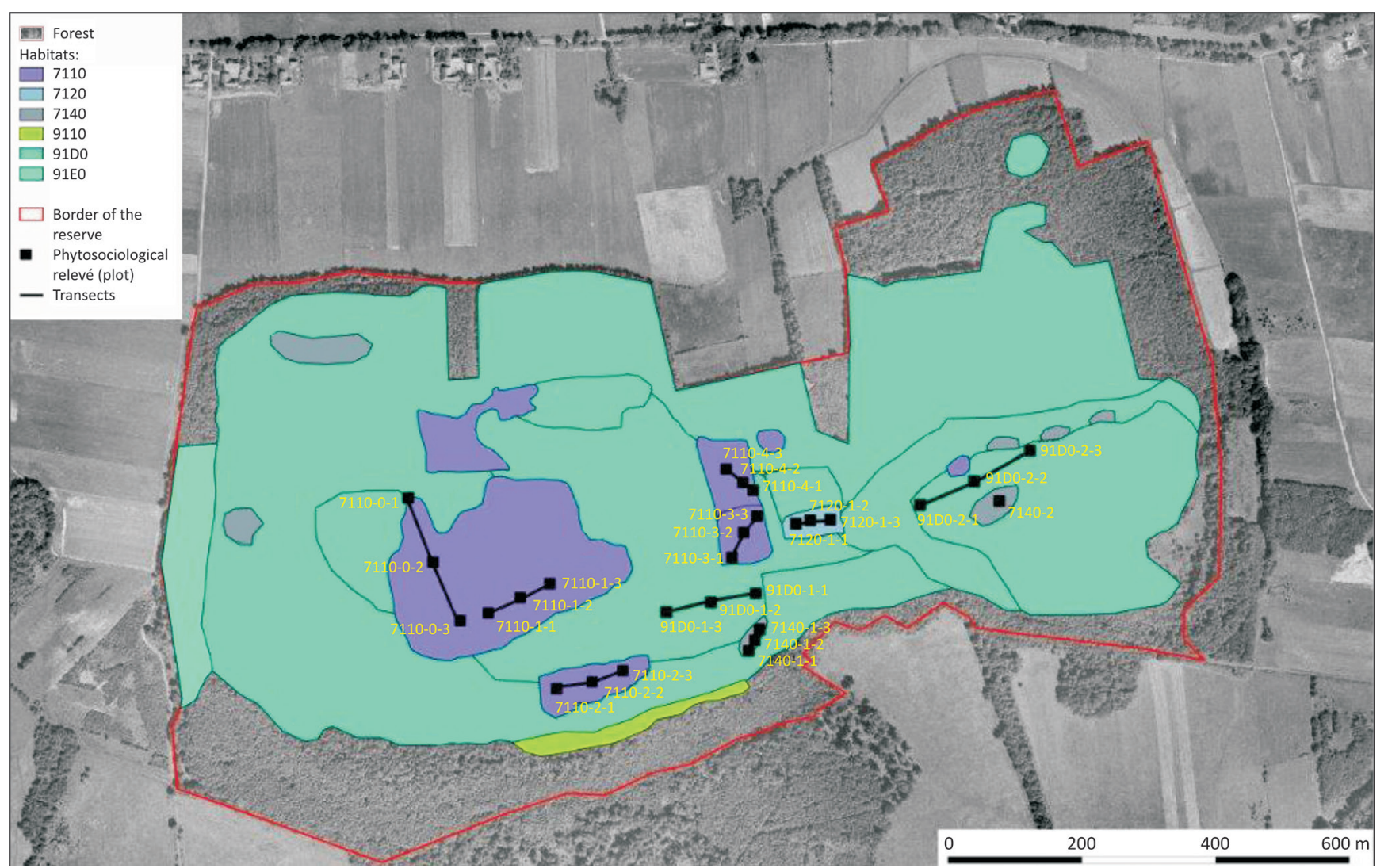

Fig. 10. Phytosociological structure and plant habitats recorded in 2011 in the swamp of Pobłockie Peatbog (Kujawa-Pawlaczyk 2011) 3160 - Natural dystrophic lakes and ponds; 4010 - Damp heaths with the crossed-leaved heath; 7110 - Raised bogs of peat-forming vegetation (live); 7120 - Degraded raised bogs, capable of natural and/or stimulated regeneration; 7140 - Transition mires and quaking bogs (mostly with vegetation of the class Scheuchzerio-Caricetea nigrae); 91D0 - Bog woodland; 91E0 - Riparian willow, poplar, alder and ash forest (Salicetum albae, Populetum albae, Alnenion glutinoso-incanae, riparian alder forest).

water bodies and damp heaths with the crossed-leaved heath. The area from the north-eastern part of the reserve, once occupied by Lake Czarne, is now flooded as a result of beaver activity. In the south-eastern part of the study area a small, overgrowing water reservoir, probably a post-exploitation peat pit, was recorded (Kujawa-Pawlaczyk 2011).

Although damp heaths with the crossed-leaved heath (4010) are listed as one of the habitats found in the swamp of Pobłockie Peatbog, it was not found during the field research. This habitat, classified earlier as damp heaths with the crossed-leaved heath, should be identified as live raised bogs (habitat 7110), with a large proportion of the crossed-leaved heath. The rationale for this claim is the high proportion of peat moss $(90 \%$ coverage) and the lack of "desiccated" peat and decayed peat patches, where Ericetum tetralicis is observed. The raised bog with the participation of the crossed-leaved heath in the swamp of Pobłockie Peatbog reserve occurs on highly waterlogged (damp) peat, with a large proportion of sphagnum bog species characteristic of raised bogs (class Oxycocco-Sphagnetea). In contrast, in damp habitats of Atlantic wet heaths the prevail- ing crossed-leaved heath grow on primarily desiccated peatland areas and develop on peaty and gley-podzolic soils. Their characteristic feature is the lack of continental and boreal species - and a vanishingly small proportion of patches of peat-forming sphagnum species (Kujawa-Pawlaczyk 2011).

Well developed and preserved patches of bog woodland (91D0) occur in several better hydrogenated places. Such forest occupies the largest proportion of the waterlogged area. The total surface area of the habitat is approx. 67.91 ha, which is approx. $60 \%$ of the swamp of Pobłockie Peatbog. Patches of desiccated forests on peat with pine-birch tree stands and groundcover, "referring to bog forests and birch woods", with some participation of bog shrubs, sometimes involving interrupted clubmoss (Lycopodium annotinum L.) are common. Often, though of little cover, the crossleaved heath is found (Erica tetralix L.). The habitats of riparian willow, poplar, alder and ash forest (91E0) or alder riparian forests are located in the western part of the swamp. They occupy an area of $2.18 \mathrm{ha}$, which is approx. $2 \%$ of the total area of the reserve. Habitats of acid lowland beech forest (9110) are located in the 
southern part of the study area and cover an area of 0.74 ha, or approx. $0.6 \%$ of the research area (Kujawa-Pawlaczyk 2011). Forest habitats in the swamp of Pobłockie Peatbog occupy more than $62 \%$ of the whole area.

Three habitats overgrown by vegetation typical of peat bogs can be distinguished in the area. They are live raised peat bog (7110), transition mires with vegetation of the class Scheuchzerio-Caricetea nigrae (7140) and degraded raised bogs capable of natural and/or stimulated regeneration (7120).

The live raised bog habitat (7110) lies in the central and western parts of the reserve. It covers an area of 10.01 hectares, which represents approx. $9 \%$ of the entire swamp of Pobłockie Peatbog. Most of the habitat patches are well developed peat moss patch-hollow areas with a large share of shrubs of the cross-leaved heath Erica tetralix, wild rosemary Ledum palustre, bog-rosemary Andromeda polifolia and common heather Calluna vulgaris. Clumps composed of hare's tail cotton grass Eriophorum vaginatum are raised over $10 \mathrm{~cm}$ in relation to the pits. A sphagnum-rich population is represented by the presence of 11 species of the genus Sphagnum $s p p$. A high proportion of shrubs have been recorded on raised bogs in the reserve (Kujawa-Pawlaczyk 2011).

Habitats of the transitional mire with the vegetation of the class Scheuchzerio-Caricetea nigrae (7140) are located in small depressions in the southern and western parts of the reserve of Pobłockie Peatbog. They occupy an area of 1.37 hectares, which represents $1.2 \%$ of the entire waterlogged area. In most cases, characteristic species are represented by two species of herbaceous plants covering $65 \%$ of the area, and two species of spore-bearing plants ( $80 \%$ coverage) characteristic of transition mires. There are no real threats to the stability of the transitional mires at the moment, but the surface of the habitat shows a tendency to decrease, and the dynamic equilibrium is unstable. There are significant changes in the spatial structure of the habitat as a result of overgrowth by trees and sprawl of the purple moor grass Molinia caerulea (Kujawa-Pawlaczyk 2011).

Degraded raised bog habitat, capable of natural and/or stimulated regeneration (7120) is located in the central part of the swamp of Pobłockie Peatbog. It covers an area of 0.35 hectares, which represents $0.3 \%$ of the entire study area. A characteristic feature of this habitat is a small number of sphagnum clumps, slight surface desiccation of peat (down to 3-5 cm) and species depletion. The vegetation composition of this type of habitat is built of species typical of live raised bogs, but the number of individual species is disturbed and varied. The habitat of the degraded raised bogs capable of natural and/or stimulated regeneration contains four species of herbaceous plants and two species of spore-bearing plants characteristic of raised bogs (Kujawa-Pawlaczyk 2011).

\section{Discussion}

Wetlands are fundamental hydrographic units in geographical space (Rolf and Taylor 2000; Rasmussen 2008). Unfortunately, they are also extremely sensitive to anthropopressure, which can be considered in both qualitative and quantitative terms (Papastergiadou et al. 2008). The main threat to their existence is human activity, which is clearly evident in the study area. According to Verones et al. (2013), the greatest human threats to wetlands are conversion and drainage. Wetland ecosystem changes take place under different management systems at the same time. A good example is the catchment of the Sea of Galilee (Cohen-Shacham et al. 2010). The analysed area is also a good example. At various times it has been differently managed, i.e. it has been used for peat extraction, for agricultural purposes through drainage, and latterly an attempt has been made to return the area to its original state (land restoration). As a result of mismanagement wetlands have shown a noticeable tendency to disappear. According to Zedler (2003) in the United States as a result of drainage of wetlands for agricultural purposes, their area has decreased by $60 \%$. Mitch and Day Jr. (2006) estimated the reduction to be about $80-90 \%$. However, according to Kath et al. (2010), since 1900 the surface area of wetlands has decreased globally by $50 \%$, which is primarily associated with agricultural activities.

In addition to direct human activity in the form of industrial peat extraction, drainage works to convert them to agricultural use, or ill-location of hydraulic structures, wetlands are also strongly affected by climate change. This is due to the correlation of changes in the water balance of wetlands with the patterns of climate change (Rouse 2002). Climate change causes the intensification of the hydrological cycle through increased evaporation, increased precipitation, higher incidence of extreme events and the occurrence of significant changes in the processes that affect the biogeochemical quality of water (Jackson et al. 2001). According to Dale (1997), climate change is one of the two most important factors influencing the evolution of not only the surface area of wetlands but also water circulation in such areas. This is important since the main water source for wetlands, also in the analysed area, is precipitation, and their hydrology results from the vertical water exchange (precipitation - evaporation). In the event of a $10 \%$ drop in summer rainfall, the durability and severity of the water deficit on wetlands, which could be particularly well observed during dry years, will probably increase. This is clearly visible in the swamp of Pobłockie Peatbog, where in dry periods surface water disappears in the vicinity of the surrounding collector ditches, and the bog becomes desiccated, which in the 
long term results in changing vegetation and disappearance of typical wetland species.

Drainage of treeless raised bogs often leads to their transition into bog woodland (Ilnicki 2002). Such a situation occurred in the swamp of Pobłockie Peatbog which was originally a treeless raised bog, and now up to $60 \%$ is covered by swamp forest, which in turn undergoes further changes due to ground desiccation.

The accumulation of coal and peat and of decayed products in wetlands has a significant impact on changes in the water balance. There is some evidence to support the idea that higher water deficits lead to an increase in carbon dioxide emissions (Rouse 1998). We should also not forget the possibility of groundwater drainage (Sharitz 2003). According to the latter author, the level of water in wetlands can vary seasonally and annually, from total flooding to desiccation so wetland habitats must be adapted to varying and often unpredictable hydrological conditions. Moreover, groundwater resources and their spatial and temporal variability are crucial for the existence of wetlands, including the swamp of Pobłockie Peatbog. Increasing demand on groundwater is considered by Piniewski et al. (2012) to be the main threat to wetland ecosystems, i.e. hydrogenic soils and wetland vegetation. The level of degradation of habitats is, therefore a consequence of the reduction in groundwater (Piniewski et al. 2012). Intense water table volatility in the analysed area testifies to the important degradation role played by changes in groundwater levels. Furthermore, according to Michener et al. (1997) climate change will affect the increasing number of extreme events and changes in sea level, which are also important for the existence and evolution of wetlands, especially those located in the coastal zone of seas and oceans. Different scenarios of climate change confirm that there will besignificant transformation of plant species in individual habitats, which will be particularly visible when the air temperature increases by $2^{\circ} \mathrm{C}$ and precipitation decreases by $60 \mathrm{~mm}$ (Dirnböck et al. 2003).

The second factor ischanging land use and land management. According to Frieswyck and Zedler (2007), the most important factor in the changes that are taking place in wetlands affectsnot only the groundwater body but also the surface water. This is because water is an integral part of the structure and functioning of wetlands, so there is a strong relationship between vegetation and changes in water level. This also overlaps with anthropopressure through the introduction of invasive species in wetlands, which by bringing about land use change and stabilising water level adjusts the historical cycle of the native vegetation in favour of invasive species. Aware that the stabilisation of the water level changes the historical cycle of vegeta- tion, the authors asked whether similar changes can occur when the water level is not stabilised. Using historical aerial photographs of three wetlands located around Lake Michigan, they found that the invasive species habitats led to the elimination of wet meadow habitats. This is because of a significant decrease in the water level. Moreover, wetlands with a visible water table are exposed to reed expansion. According to a study by $\mathrm{Pa}$ pastergiadou et al. (2008) conducted with GIS tools for the wetlands of Lake Cheimaditida located in northern Greece, over a period of about 50 years the area taken up by the reed increased by $19 \%$ while the surface area of open water and open bogs decreased by $99.5 \%$. Reed growth may be influenced by an uncontrolled influx of nutrients, especially nitrogen compounds (Mitch and Day Jr. 2006). Some disturbing elements in the correct reading of natural water level changes include topography, exposure and the properties of sediments (Hudon et al. 2006). According to Boudreau and Rouse (1995), the individual characteristics of the various types of wetlands, including location, topography, existing substrate, hydrographic conditions and biotic characteristics determine the diversity the water balance in the area.

The impact of the changes that are taking place on the wetlands stems not only from the negative effect of human activities, but is also results from attempts to restore their original state, i.e. from before their anthropogenisation. Attempts to restore wetland ecosystems, namely land reclamation, can lead to many significant changes in both the biotic environment and the abiotic environment, including hydrology (Gawlik 2006). One of the dominant gradients of wetlands is a continuum of depth and water supply frequency. Although much emphasis has been placed on the importance of hydrology as a force for wetlands, several other elements may also have an impact. In contrast to the continuum of humidity, the functioning of wetlands can be divided, according to Brinson (1993), into two categories i.e. the transformation of the landscape and the resourcebased transition that allows a comparison of water flow and processing of nutrients. The landscape continuum involves the transition from the top to the bottom of wetlands and between aquatic and land ecosystems within the wetland. Between the input and output of the wetland area there are numerous changes in water supply sources, including the discharge of groundwater and surface runoff from small streams or large rivers. Simultaneously, the author stated that fragments of flooded or saturated wetlands are no less active than those more damp, and the only difference lies in the different functioning of the various components (functions are only different). In the swamp of Pobłockie Peatbog with the change in the amount of water sup- 
ply (drainage) a succession of other plant species took place. The places where wet heaths with the cross-leaved heath were observed in the past have been overtaken by live raised bog habitats.

\section{Conclusions}

The hydrographic changes that have taken place in the swamp of Pobłockie Peatbog have affected the vegetation in the area. Some plant species have been replaced by others, while in many cases along with the lowering of the groundwater level, some plant species that require damp conditions to develop have disappearedas, for instance, in the case of the cross-leaved heath.

Long-term drainage and the construction of new drainage ditches have led to the encroachment of bog woodland on the originally treeless swamp of Pobłockie Peatbog. The effect is a loss of large bog areas, replaced by forest communities.

Changes in the hydrographic network are clearly visible. Over the years the waterlogged area was transformed by human activity from a naturally treeless wetland to a desiccated region with a small amount of water. The swamp was drained to acquire land for agriculture. The area was also used as a source of peat that was extracted mainly in the northern part of the waterlogged area. However, with the passage of time overexploitation no longer occurs and the approach to wetlands has changed completely. What was realised is the uniqueness of wetlands and an attempt was undertaken to restore those areas to their natural appearance and function. Currently, we can see the first effects of the attempts to repair the environment of the area by increasing soil moisture, creating a shallower groundwater volume and increased surface with the water constantly visible. Such a rapid pace of change in the water conditions has resulted not only from human activity but also from a natural factor, which in this case is the activity of beavers.

Summing up, for wetlands the key to effective water resource management is understanding that the water cycle and land management are inextricably linked: that every land use decision is a water use decision.

\section{References}

Antonellini M., Mollema P.N., 2010, Impact of groundwater salinity on vegetation species richness in the coastal pine forests and wetlands of Ravenna, Italy, Ecol. Eng. 36(9): 1201-1211.
Boudreau L.D., Rouse W.R., 1995, The role of individual terrain units in the water balance of wetland tundra, Climate Res. 5(1): 31-47.

Brinson M.M., 1993, Changes in the functioning of wetlands along environmental gradients, Wetlands 13(2): 65-74.

Brooks T.R., 2004, Weather - related effects on woodland vernal pool hydrology and hydroperiod, Wetlands 24(1): 104-114.

Brooks R.T., 2005, A review of basin morphology and pool hydrology of isolated ponded wetlands: implications for seasonal forest pools of the northeastern United States, Wetl. Ecol. Manag. 13: 335-348.

Brooks T.R., Hayashi M., 2002, Depth-area-volume and hydroperiod relationships of ephemeral (vernal) forest pools in southern New England, Wetlands 22(2): 247-255.

Cohen-Shacham E., Dayan T., Feitelson E., de Groot R.S., 2010, Ecosystem service trade-offs in wetland management: drainage and rehabilitation of the Hula, Israel, Hydrolog. Sci. J. 56(8): 1582-1601.

Dale W.H., 1997, The relationship between land-use change and climate change, Ecol. Appl. 7(3): 753-769.

Davis S.M., Childers D.L., Lopez J.J., Wanless H.R., Hopkins T.E., 2005, A conceptual model of ecological interactions in the mangrove estuaries of the Florida Everglades, Wetlands 25(4): 832-842.

Dirnböck T., Dullinger S., Grabherr G., 2003, A regional impact assessment of climate and land-use change on alpine vegetation, J. Biogeogr. 30(3): 401-417.

Frieswyk Ch.B., Zedler J.B., 2007, Vegetation Change in Great Lakes Coastal Wetlands: Deviation from the Historical Cycle, J. Great Lakes Res. 33(2): 366-380.

Gallant J.C., Wilson J.P., 2000, Primary terrain attributes, [in:] Wilson J.P., Gallant J.C. (eds), Terrain analysis: Principles and applications, Wiley, New York: 51-85.

Gawlik D.E., 2006, The role of wildlife science in wetland ecosystem restoration: Lessons from the Everglades, Ecol. Eng. 26(1): 70-83.

Hudon Ch., Wilcox D., Ingram J., 2006, Modeling Wetland Plant Community Response to Assess Water-Level Regulation Scenarios in the Lake Ontario - St. Lawrence River Basin, Environ. Monit. Assess. 113(1-3): 303-328.

Ilnicki P., 2002, Torfowiska i torf (Peatlands and peat), Wydaw. ARPoz., Poznań, 606 pp. (in Polish).

Jackson R.B., Carpenter S.R., Dahm C.N., McKnight D.M., Naiman R.J., Postel S.L., Running S.W., 2001, Water in a changing World, Ecol. Appl. 11(4): 1027-1045.

Jahangir M.M.R., Johnston P., Addy K., Khalil M.I., Groffman P.M., Richards K.G., 2013, Quantification of in situ denitrification rates in groundwater below and arable and a grassland system, Water, Air, Soil Pollut. 224(9): 1693.

Kath J., Le Brocque A., Miller C., 2010, Eco-hydrology of dynamic wetlands in an Australian agricultural landscape: a whole of system approach for understanding climate change impacts, [in:] Proc. of the BALWOIS Conference: Water Observation and Information System for Decision Support, 25-29 May 2010, Ohrid: 1-13. 
Krysanova V., Hattermann F., Wechsung F., 2005, Development of the ecohydrological model SWIM for regional impact studies and vulnerability assessment, Hydrol. Process. 19(3): 763-783.

Kujawa-Pawlaczyk J., 2011, Rezerwat przyrody „Torfowisko Pobłockie". Ocena wpływu metod ochrony i stanu zachowania siedlisk przyrodniczych (The nature reserve „Pobłockie Peatbog”. Evaluation of the effects of the conservation measures and the state of preservation of natural habitats) [manuscript], Szamotuły (in Polish).

Leider A., Hinrichs K.U., Schefuß E., Versteegh G.J.M., 2013, Distribution and stable isotopes of plant wax derived $\mathrm{n}$-alkanes in lacustrine, fluvial and marine surface sediments along an Eastern Italian transect and their potential to reconstruct the hydrological cycle, Geochim. Cosmochim. Acta 117: 16-32.

McPhillips L.E., Groffman P.M., Goodale Ch.L., Walter M.T., 2015, Hydrologic and Biogeochemical Drivers of Riparian Denitrification in an Agricultural Watershed, Water, Air, Soil Pollut. 226: 169.

Michener W.K., Blood E.R., Bildstein K.L., Brinson M.M., Gardner L.R., 1997, Climate change, hurricanes and tropical storms, and rising sea level in coastal wetlands, Ecol. Appl. 7(3): 770-801.

Miguez-Macho G., Fan Y., 2012, The role of groundwater in the Amazon water cycle: 1 . Influence on seasonal streamflow, flooding and wetlands, J. Geophys. Res. Atmos. 117(D15113): 1-30.

Mitsch W.J., Day Jr. J.W., 2006, Restoration of wetlands in the Mississippi-Ohio-Missouri (MOM) River Basin: Experience and needed research, Ecol. Eng. 26(1): 55-69.

Muller I., Buisson E., Mouronval J.B., Mesléard F., 2013, Temporary wetland restoration after rice cultivation: is soil transfer required for aquatic plant colonization?, Knowl. Manag. Aquat. Ecosyst. 411(03):1-17.

Nuttle W.K., Hemand H.F., 1988, Salt marsh hydrology: Implications for biogeochemical fluxes to the atmosphere and estuaries, Global Biogeochem. Cycles 2(2): 91-114.

Oertli B., Biggs J., Céréghino R., Grillas P., Joly P., Lachavanne J.B., 2005, Conservation and monitoring of pond biodiversity: introduction, Aquat. Conserv. 15(6): 535-540.

Papastergiadou E.S., Retalis A., Apostolakis A., Georgiadis Th., 2008, Environmental Monitoring of Spatio-temporal Changes Using Remote Sensing and GIS in a Mediterra- nean Wetland of Northern Greece, Water Resour. Manag. 22(5): 579-594.

Piniewski M., Gottschalk I., Krasovskaia I., Chormański J., 2012, A GIS-based model for testing effects of restoration measures in wetlands: A case study in the Kampinos National Park, Poland, Ecol. Eng. 44: 25-35.

Rasmussen T., 2008, Methods for evaluating wetland condition, Wetland Hydrology 20: 1-37.

Rijsberman F.R., 2006, Water scarcity: Fact or fiction?, Agr. Water Manage. 80(1-3): 5-22

Roff J.C., Taylor M.E., 2000, National frameworks for marine conservation - a hierarchical geophysical approach, Aquat. Conserv. 10(3): 209-223.

Rouse W.R., 1998, A water balance model for a Subarctic Sedge Fen and its application to climatic change, Clim. Change 38(2): 207-234.

Rouse W.R., 2002, The energy and water balance of high-latitude wetlands: controls and extrapolation, Glob. Change Biol. 6(Suppl. 1): 59-68.

Sharitz S.R., 2003, Carolina bay wetlands: Unique habitats of the southeastern United States, Wetlands 23(3): 550-562.

Stefanidis K., Papastergiadou E., 2013, Effects of a long term water level reduction on the ecology and water quality in an eastern Mediterranean lake, Knowl. Manag. Aquat. Ecosyst. 411(05): 1-14.

Tiner R.W., 2003, Geographically isolated wetlands of the United States, Wetlands 23(3): 494-516.

Verones F., Saner D., Pfister S., Baisero D., Rondinini C., Hellweg S., 2013, Effects of Consumptive Water Use on Biodiversity in Wetlands of International Importance, Environ. Sci. Technol. 47(21): 12248-12257.

Whitefield P.H., Hebda R.J., Jeglum J.K., Howie S., 2006, Restoring the natural hydrology of Burns Bog, Delta, British Columbia - the key to the bog's ecological recovery, [in:] Chantler A. (ed.), Water under pressure. Proc. of the CWRA Conference, October 2006, Vancouver: 38-52.

Wilcox D.A., Meeker J.E., Hudson P.L., Armitage B.J., Black M.G., 2002, Hydrologic variability and the application of index of biotic integrity metrics to wetlands: a Great Lakes evaluation, Wetlands 22(3): 588-615.

Zedler J.B., 2003, Wetlands at your service: reducing impacts of agriculture at the watershed scale, Front. Ecol. Environ. 1(2): 65-72. 